\title{
Investigating the Preservice Primary School, Mathematics and Science Teachers' STEM Awareness
}

\author{
Hasan Bakırc1 ${ }^{1}$, Dilek Karışan ${ }^{2}$ \\ ${ }^{1}$ Yuzuncu Y1l University, Turkey \\ ${ }^{2}$ Adnan Menderes University, Turkey \\ Correspondence: Dilek Karışan, Adnan Menderes University, Turkey
}

Received: November 21, 2017

Accepted: December 10, 2017 Online Published: December 10, 2017

doi:10.11114/jets.v6i1.2807

URL: https://doi.org/10.11114/jets.v6i1.2807

\begin{abstract}
Today's life requires individuals to be prepared for complex world environment, to make complex decisions, and to have critical thinking skills related to everyday life issues at hand. STEM education is thought to be the glorious solution to thrive in a global knowledge driven world. Teachers are key elements for successful STEM education. Present study aims to investigate the preservice primary school, mathematics and science teachers STEM awareness. Quantitative research methodology guided the present study. Cross-sectional survey type which collects information from a sample that has been selected from a predetermined population was used. Stem Awareness Scale, a five point Likert type instrument developed by Buyruk and Korkmaz (2016), was used to measure preservice teachers STEM awareness. Data was collected from 558 (371 female, 187 male) preservice teachers enrolled in three different teacher preparation programs. The results of this research demonstrates that there is no significant interaction effect for gender and department variables however there is significant difference among different department students STEM awareness preservice science teachers' and preservice primary school teachers STEM awareness scores have similar mean values and also outnumbers the preservice mathematics teachers' STEM awareness.
\end{abstract}

Keywords: STEM awareness, preservice teachers, primary teachers, preservice mathematics teachers

\section{Introduction}

Today's life requires individuals to be prepared for complex world environment, to make complex decisions, and to have critical thinking skills related to everyday life issues at hand (Kennedy and Odell, 2014). In line with this need, all countries, especially the developed ones, have tried to find ways to become powerful in global economy by training qualified individuals. Since education to be given in the fields of science, mathematics and technology is important for training qualified individuals, the related curricula should not be isolated from daily life (National Research Council [NRC], 2012). It is reported that in many countries including the United States of America, there is a year-by-year decrease in the number of students willing to take education in the fields of science, mathematics and engineering (Stohlmann, Moore and Roehrig, 2012). This situation is thought to lead to the problem of human force that can use and adapt scientific and technological knowledge in future (Turkish Association of Industrialists and Businessmen [TÜSİAD in Turkish], 2014). In order to avoid such problem and to compete in global scale, countries intend to train individuals who can use and apply different disciplines together. As educators are aware of the fact that education is necessary to train individuals, they have always focused on the need for updating the curricula constantly. It could be stated that the idea of educating qualified individuals and to help them develop the 21 st century competencies are influential on updating the curricula. In recent years, a number of countries have included the STEM approach in all education levels, which is based on the integration of science, technology, engineering and mathematics (Bybee, 2010; Çorlu, 2014). In this way, STEM approach has become an indispensable part of the $21^{\text {st }}$ century curricula (NRC, 2012).

STEM is an interdisciplinary approach that adopts the need for teaching the fields of science, technology, engineering and mathematics in an integrated manner (Çorlu, Capraro and Capraro, 2014; Ercan and Şahin, 2015). The fact that countries like USA, China, Japan and Russia are in a competition of global power and that USA is anxious about staying behind the other countries in this competition has featured the integrated STEM education. Based on the fact that China has developed rapidly especially in economic and technological areas as well as in the area of defense industry could pose a threat, USA has performed educational reforms. Another factor that caused USA to perform these 
reforms was the decrease in the number of students preferring the STEM career fields in the country (Sanders, 2009). This situation results from students' negative attitudes towards these disciplines, from lack of qualified teachers and from abstraction of curricula from daily life (Bissaker, 2014; Hudson, 2014). International research carried out on STEM Education have also drawn the attention of Turkish science educators. The results of related studies demonstrate that the problems with the STEM education in developed countries do exist in Turkey as well (Akgündüz, Aydeniz, Çakmakçı, Çavaş, Çorlu, Öner and Özdemir, 2015). Akgündüz et al. (2015) in their comprehensive review on STEM education reported the number of the students who passed the university placement exam and preferred engineering and science departments between 2000 and 2014 in Turkey. The results revealed that the number of the students who preferred the STEM career fields based on their scores in the university placement exam decreased year by year. On the other hand, among the students who responded to the mathematical part of the university place exam taking place in the first 1000-successful-student list and who preferred the STEM fields, the ratio of the male students was $81,39 \%$, while it was $18,61 \%$ for the female students (Akgündüz, et.al., 2015). This result demonstrates that in Turkey, female students have disadvantages in STEM career fields when compared to male students. Considering the fact that students do not prefer STEM fields in their career preferences and that there are serious differences between male and female students preferring these fields, STEM education reports were published throughout the country, and various institutions (TÜSİAD, 2014; Ministry of National Education [MoNE], 2016) prepared reports to solve the related problems. All these reports demonstrated that STEM education is important for the country, and they put forward various suggestions such as establishing cooperation between universities, industries and businesses for effective STEM education and integrating STEM education activities into curricula. In line with these suggestions, K-8 science curriculum in Turkey updated in 2017 and new courses which focuses on science and technology namely "Applied Science Learning" was included in the curriculum. In this respect, the lesson unit of "Science and Engineering Practices" was added to the textbook (MoNE, 2017).

K-8 Science curriculum aims to help students discover the information, use that information in their daily life and make it meaningful rather than to evaluate their levels of current knowledge (MoNE, 2017). STEM education has an important place in achieving this purpose by letting students to combine a number of disciplines and learn how to reach the information and how to solve real-world problems by doing and experiencing. In addition, STEM education enhances individuals' technology and scientific literacy STEM education allows students to recognize more than one possible solution to a problem and to develop various skills such as metacognitive thinking skills, questioning skills, scientific process skills and cooperative learning skills (Ercan and Bozkurt, 2013; Marulcu, 2010; NRC, 2012; Schnittka and Bell, 2011). Individuals also learn scientific concepts and acquire problem solving skills by engaging engineering designs. Moreover, this situation will increase individuals' motivations in lessons and draw their attention to lesson subjects. In addition, STEM education is also thought to be important for the development of students' decision-making skills (Jonansen, 2011; Kennedy and Odell, 2014). In the process of STEM education, individuals face problem situations with more than one solution, and they are expected to choose the most appropriate solution to such problem situations. Finding the best solution will demonstrate that individuals can use skills and knowledge required by more than one discipline and that their decision-making skill has developed. Individuals who have developed their decision-making skill will be able to choose one of the possible solutions to daily-life problems without any hesitation (Denson, 2011; Tezel \& Yaman, 2017). It is also understood that the goals of STEM education have overlap those of the curricula.

Teachers, who are practitioners of curricula, have important duties. In this respect, teacher preparation programs have utmost importance teaching preservice teachers' how to integrate STEM into their classroom practice preservice teachers (PT) are supposed to know about the learning areas in the curricula during the undergraduate education, and it is important to know the extent of PTs' STEM awareness. The fact that one of the recent approaches in K-8 curricula is the STEM education has made it important to determine the related awareness of science, mathematics and primary school teachers. The reason is that these preservice teachers will become the practitioners of the curricula at schools where they will be employed. The STEM approach plays an important role in using the interdisciplinary knowledge and skills cooperatively as well as in training qualified human force (Çorlu, Capraro, \& Capraro, 2014; Kennedy and Odell, 2014). The teacher does not have the role of giving theoretical information in STEM fields but an assistive role of providing guidance and developing the product (MoNE, 2016). Teachers should be trained well enough to encourage students and to teach the $21^{\text {st }}$ century skills such as problem solving, creativity and critical thinking. For this purpose, starting from teacher preparation program, it is necessary for them to acquire the necessary knowledge and skills and to raise their awareness of STEM fields (Buyruk and Korkmaz, 2016; MoNE, 2016). In this respect, several studies have pointed out that it is necessary to determine preservice teachers' STEM awareness (Buyruk and Korkmaz 2016; Faber, Unfried, Wiebe, Corn, Townsend, and Collins, 2013; Gökbayrak and Karışan, 2017a). The reason is that preservice teachers will teach their courses based on this teaching approach when they start teaching professionally. 
With the inclusion of the STEM approach into the curricula, a number of national and international studies have been conducted. While there are numerous related studies carried out abroad, there is little research on this subject in our country. When the related studies in national literature are examined, it is seen that one study was carried out on the development of STEM Awareness Scale (Buyruk and Korkmaz, 2016); that there were some studies revealing the positive influence of after-school activities regarding STEM on the development of the $21^{\text {st }}$ century skills (Şahin, Ayar and Adıgüzel, 2014; Gökbayrak and Karışan, 2017b); and that some other studies were conducted to examine the influence of STEM activities on elementary school fifth grade students' scientific process skills and on their attitudes towards science (Yamak, Bulut, Dündar, 2014). In addition, it was also found that STEM education and engineering applications were influential on the development of preservice science teachers' academic achievements (Yıldırım and Altun, 2015); that preservice science teachers had more positive attitudes towards STEM when compared to preservice mathematics teachers (Yenilmez and Balbağ, 2016); that STEM-based education allow individuals to learn by doing, to increase their motivation, to learn permanently and to develop their questioning skills (Bozkurt- Altan, Yamak and Buluş-Kırıkkaya, 2016, Karışan and Yurdakul, 2017); and that engineering-related science teaching was influential on increasing preservice teachers' scientific creativity (Hacıŏglu, Yamak and Kavak, 2016).

In addition, it was also revealed that STEM education is influential on the acquisition of the $21^{\text {st }}$ century skills (Bybee, 2010; Wagner, 2008); that STEM-aided courses increase preservice teachers' self-efficacies and their interest in and attitudes towards science (Bracey and Brooks, 2013); that science teachers have positive views about STEM applications (Capobianco, 2013); that primary school teachers believe in the importance of the STEM application but due to their lack of knowledge about this approach they reported low self-confidence about integrating STEM into their courses (Hsu, Purzer and Cardella, 2011); and that engineering-related activities carried out during lessons contribute to concept teaching and increase chemistry teachers' awareness of the discipline of engineering (Apedoe, Reynolds, Ellefson and Schunn, 2008). A STEM-based holistic education was also found to be influential on students' academic achievements, concept learning, interests, motivations and attitudes (Baran, Canbazoğlu Bilici and Mesutoğlu, 2015; Gülhan and Şahin, 2016; Şahin, Ayar and Adıgüzel, 2014).

When the related literature is examined, it is seen that STEM teachers do not have the necessary interdisciplinary training on (Stinson, Harkness, Meyer and Stallworth, 2009); that it is important to recognize the importance of engineering education in an early years like elementary school and secondary school levels (Kimmel, Carpinelli and Rockland, 2007); that it is necessary to develop students' STEM skills at early ages (Robinson, Dailey, Hughes and Cotabish, 2014); and that the number of studies and attempts regarding STEM education should be increased at education faculties to train more qualified teachers and preservice teachers, who are all practitioners of STEM (Akaygün and Aslan-Tutak, 2016). In this respect, as science, mathematics and primary school preservice teachers will start teaching professionally in future, it is fairly important to determine this problem during individuals' university education. Teachers have important duties as practitioners of the STEM education approach and as designers of learning environments. Therefore, in the present study, the purpose was to investigate the preservice science, mathematics and primary school teachers' STEM awareness. For this purpose, the following research problem guided the study:

Research Problem: What is the level of preservice teachers STEM awareness and does this level differ in regard to their department, gender, and grade level?

This research problem was explored by following research questions;

1) Are there any differences among preservice primary school, mathematics and science teachers' STEM awareness?

2) Are there any differences among preservice primary school, mathematics and science teachers' STEM awareness with respect to gender?

3) Are there any differences among preservice primary school, mathematics and science teachers' STEM awareness with respect to grade level?

\section{Method}

\subsection{Research Design}

Quantitative research methodology guided the present study. Researchers used survey method to investigate the preservice Primary school, Mathematics and Science Teachers' STEM Awareness. Survey method is often used by the researchers to explore opinions of a large group of sample about a specific unit of analysis (Fraenkel \& Wallen, 2003). Present study used cross-sectional survey type which collects information from a sample that has been selected from a predetermined population. Information is collected at just one point in time in 2017-2018 autumn semester from a particular sample (preservice primary school, mathematics and science teachers) via using STEM awareness scale. 


\subsection{Sample \& Population}

Data was collected from the preservice teachers in Yuzuncu Y1l University registered at the department of primary school, mathematics and science teacher education program (at all grade levels) in 2017-2018 autumn semester. Scale was directly administered to 558 preservice teachers ( 371 female, 187 male) by the first author. Participants ranged in age from 18 to 26 with a mean age of 24.29 years. Convenience sampling method was used. Researcher had an opportunity to explain the study and answer any questions before the students responded to the instrument.

\subsection{Data Collection Tool}

Stem Awareness Scale developed by Buyruk and Korkmaz (2016), was used to measure preservice teachers STEM awareness. The scale consists of 17 questions and two subscales which are; positive (includes 12 items) and negative (includes 5 item) factors. It is a five-point Likert type scale anchored with 1 (Strongly Disagree) and 5 (Strongly Agree). The highest score to be taken from the scale was $5 \times 17=85$ points, the lowest was $1 \times 17=17$ points. One sample item from the instrument is "STEM education encourages students to learn". Coefficient alpha estimate of reliability was found to be .88 .

\section{Results}

Present study aimed to explore preservice teachers STEM awareness and aimed to investigate is there a gender, science major and grade level difference in preservice teachers STEM awareness? Descriptive statistics with respect to department, grade level and gender are presented in Table 1.

Table 1. Distribution of the departments and genders of all grade levels

\begin{tabular}{lllllll}
\hline & & 1. Grade & 2. Grade & 3. Grade & 4. Grade & Total \\
\hline Science & Female & 30 & 34 & 35 & 39 & 138 \\
& Male & 9 & 6 & 13 & 22 & 50 \\
Mathematics & Female & 17 & 11 & 22 & 25 & 75 \\
& Male & 11 & 13 & 10 & 8 & 42 \\
Primary school & Female & 36 & 32 & 50 & 40 & 158 \\
& Male & 19 & 25 & 32 & 19 & 95 \\
Total & & 122 & 121 & 162 & 153 & 558 \\
\hline
\end{tabular}

Table1 summarizes the numbers of the preservice teachers across all grade levels and all departments. There were 188 preservice science teachers, 117 preservice mathematic teachers and 253 preservice primary school teachers. The numbers of the students from different departments were close to each other however there were two branches (first branch came to school at day time, second branch came to school at night time) for primary school teachers so their numbers were outnumbered than other departments. The number of the female students $(n=371)$ were twice as much of the numbers of male student $(\mathrm{n}=187)$. This difference is reasonable since the data was collected from education faculty and being a teacher is very common for girls in Turkey.

\subsection{Department and Gender Effect on Preservice Teachers'STEM Awareness}

In order to answer the first and second research question (What is the level of preservice teachers STEM awareness and does this level differ in regard to their gender and department?), preservice teachers were asked about their awareness regarding STEM. As shown in Table 2 preservice teachers average STEM awareness ranged between 3.80 and 4.10 which are above the mid-point (3) of 5 point Likert Scale. Table 2 shows that female and male students, registered in different majors (science, mathematics, primary school), responses are close to each other at each major. Two-way analysis of variance (two way-ANOVA) was conducted to examine the department (Science, Mathematics, Primary school) and gender differences in students STEM awareness by checking the assumptions of the test which are;

The observation within each sample must be independent

The populations from which the samples are selected must be normal

The populations from which the samples are selected must have equal variance (Gravetter \& Wallnau, 2004, p.432).

Table 2. Two way ANOVA results with respect to gender and department

\begin{tabular}{lrrrrr}
\hline Source & \multicolumn{1}{c}{ SS } & df & MS & F & Sig. \\
\hline Gender & .58 & 1 & .58 & 1.65 & .19 \\
Department & 3.25 & 2 & 1.62 & 4.60 & .01 \\
Gender* Dept. & .40 & 2 & .20 & .56 & .56 \\
Error & 194.84 & 552 & .353 & & \\
Total & 9170.39 & 558 & & & \\
\hline
\end{tabular}

a. $\mathrm{R}$ Squared $=.021$ (Adjusted R Squared $=.012$ )

Results illustrates that there is no significant interaction effect for gender and department variables $[F(2,552)=.56$, 
$\mathrm{p}=.56]$. Moreover, no significant main effects for gender $[\mathrm{F}(1.552)=1.65, \mathrm{p}=.19]$ however there is significant difference among different department students STEM awareness $[\mathrm{F}(2.552)=4.60, \mathrm{p}=.01]$ were found.

Table 3. Descriptive statistics for male and female preservice science, mathematics and primary school teachers' STEM awareness

\begin{tabular}{|c|c|c|c|c|}
\hline Department & Gender & $\overline{\mathrm{x}}$ & $S$ & $\mathrm{~N}$ \\
\hline \multirow[t]{2}{*}{ Science } & Female & 4.08 & .60 & 138 \\
\hline & Male & 4.10 & .46 & 50 \\
\hline Total & & 4.09 & .56 & 188 \\
\hline \multirow[t]{2}{*}{ Mathematics } & Female & 3.92 & .63 & 75 \\
\hline & Male & 3.80 & .51 & 42 \\
\hline Total & & 3.88 & .59 & 117 \\
\hline \multirow[t]{2}{*}{ Primary school } & Female & 4.04 & .58 & 158 \\
\hline & Male & 3.94 & .65 & 95 \\
\hline Total & & 4.00 & .61 & 253 \\
\hline
\end{tabular}

Preservice science teachers' ( $\overline{\mathrm{X}}=4.09)$ and preservice primary school teachers $(\overline{\mathrm{X}}=4.00)$ STEM awareness scores have similar mean values and outnumbers the preservice mathematics teachers' ( $\overline{\mathrm{x}}=3.88)$ STEM awareness.

\subsection{Department and Grade Level Effect on Preservice Teachers'STEM Awareness}

In order to answer the last research question (Does preservice teachers' STEM awareness differ in regard to grade level?), preservice teachers were asked about their STEM awareness As shown in Table 4, Freshman $(\overline{\mathrm{x}}=4.09)$ sophomore $(\overline{\mathrm{X}}=4.14)$ and senior $(\overline{\mathrm{X}}=4.28)$ preservice science teachers responses were close to each other and slightly differs from junior $(\overline{\mathrm{X}}=3.79)$ preservice science teachers. On the other hand, freshman $(\overline{\mathrm{X}}=3.78)$ and senior $(\overline{\mathrm{X}}=3.67)$ preservice mathematics teachers STEM awareness were lower than sophomore $(\overline{\mathrm{X}}=4.04)$ and junior $(\overline{\mathrm{X}}=4.06)$ preservice mathematics teachers. On the contrary, freshman $(\bar{x}=4.10$. $)$ and senior $(\bar{x}=4.06)$ preservice mathematics teachers STEM awareness were higher than sophomore $(\overline{\mathrm{X}}=3.88)$ and junior $(\overline{\mathrm{X}}=3.98)$ preservice mathematics teachers. Although there are slight differences among preservice teachers STEM awareness with respect to grade level, this difference were not significant.

Table 4. Descriptive statistics for freshman, sophomore, junior and senior preservice science, mathematics and primary school teachers' STEM awareness

\begin{tabular}{|c|c|c|c|c|}
\hline Department & Grade & $\overline{\bar{x}}$ & $\mathrm{~S}$ & $\mathrm{~N}$ \\
\hline \multirow[t]{4}{*}{ Science } & 1 & 4.09 & .45 & 39 \\
\hline & 2 & 4.14 & .45 & 40 \\
\hline & 3 & 3.79 & .48 & 48 \\
\hline & 4 & 4.28 & .66 & 61 \\
\hline \multirow[t]{4}{*}{ Mathematics } & 1 & 3.78 & .48 & 28 \\
\hline & 2 & 4.04 & .52 & 24 \\
\hline & 3 & 4.06 & .44 & 32 \\
\hline & 4 & 3.67 & .76 & 33 \\
\hline \multirow[t]{4}{*}{ Primary school } & 1 & 4.10 & .61 & 55 \\
\hline & 2 & 3.88 & .64 & 57 \\
\hline & 3 & 3.98 & .65 & 82 \\
\hline & 4 & 4.06 & .50 & 59 \\
\hline
\end{tabular}

Two-way analysis of variance (two way- ANOVA) was conducted to examine the department (Science, Mathematics, Primary school) and grade level $(1,2,3,4)$ differences in students STEM awareness by checking the assumptions of ANOVA.

Table 5. Two way ANOVA results with respect to grade level and department

\begin{tabular}{lccccc}
\hline \multicolumn{1}{c}{ Source } & SS & df & MS & F & Sig. \\
\hline Grade & .45 & 3 & .15 & .45 & .71 \\
Department & 2.50 & 2 & 1.25 & 3.71 & .02 \\
Grade* Dept. & 10.61 & 6 & 1.76 & 5.24 & .00 \\
Error & 184.14 & 546 & .337 & & \\
Total & 9170.39 & 558 & & & \\
\hline
\end{tabular}

a. $\quad$ R squared $=.075$ (Adjusted $\mathrm{R}$ Squared $=.056$

Results illustrates that, there is no significant main effects for grade level $[F(3.546)=.45, p=.71]$. However there is significant difference among different department students STEM awareness $[\mathrm{F}(2.546)=3.71, \mathrm{p}=.02]$, and there is significant interaction effect for grade level and department variables $[\mathrm{F}(6.546)=5.24, \mathrm{p}=.00]$. 


\section{Discussion and Conclusion}

Lack of strategies related to STEM education is one of the most important causes of the failure in STEM (Seymour and Hewett, 1997). In order to develop effective strategies in STEM education, it is necessary to raise teachers' STEM awareness. In this respect, it is important to determine preservice teachers' STEM awareness during their undergraduate education. In the present study, it was found that science and primary school preservice teachers' STEM awareness were higher than preservice mathematics teachers. Recent changes in K-8 science curriculum in Turkey might be the reason for this. Within the scope of this change, "Applied Science Learning" was added to the curriculum, and the lesson unit of "Science and Engineering Applications" was included in the related course book (MoNE, 2017). Updates in the curriculum are highlighted in some pedagogical courses such as Science Teaching Method course and Science \& Technology courses during teacher education programs as they will be the future teachers who are going to apply this curriculum in future, The courses of Science Teaching Method course given in the department of Elementary Science Education and the courses of Science and Technology I and II given in the department of Primary School Teacher cover the learning areas of STEM in the curriculum. STEM education is one of the learning areas newly added to the curriculum These courses address the history of STEM education, definition of it and the reason for its inclusion in K-8 curriculum. Therefore, the science and elementary school preservice teachers' levels of awareness of were higher than those of the preservice mathematics teachers. In the present study, the results regarding the science, mathematics and elementary school preservice teachers' levels of STEM awareness are parallel to those obtained in many other studies in related literature. Yenilmez and Balbağ (2016) revealed that the preservice science teachers had more positive attitudes towards STEM than the secondary school preservice mathematics teachers. In another study carried out with elementary school preservice teachers, Sümen and Çalışıı (2016) reported that the elementary school preservice teachers found STEM education effective, easy and entertaining. In addition, the researchers also revealed that the elementary school preservice teachers would use the STEM approach in their lessons in their future teaching lives. All these results demonstrate that the elementary school preservice teachers participating in the study carried out by Sümen and Çalışı1cı (2016) were aware of STEM and that they had positive attitudes towards it.

The fact that preservice teachers from different departments had high levels of STEM awareness is considered to be important for the future of STEM education. Teachers are expected to know effective teaching methods and to have adequate STEM understandings in order to enhance students STEM understandings. (Colbeck, O'Meara and Austin, 2008). In order for preservice teachers to develop their skills in STEM teaching, they should first be aware of STEM. In addition, teaches should make efforts to increase students' interest in STEM career areas (MacDonald and Korinek, 1995), which can be achieved by teachers with high levels of STEM awareness. Teachers are not the only ones whose STEM awareness should be raised. It is important to raise STEM awareness of all individuals in a society (Fariweather, 2008; Tezel \& Yaman, 2017). As science and mathematics are among the four main disciplines of STEM, science and mathematics teachers' STEM awareness are thought to be especially important. In addition, in order to be successful in STEM education, it is necessary to build solid bases in early school years (Sümen and Çalışıcı, 2016). Due to this necessity, preservice primary school teachers have important roles for the future of STEM education.

Gender was another variable taken into consideration in the present study. The study investigated whether the preservice teachers' STEM awareness differed with respect to their gender, and it was found that gender was not significant factor on the participants' STEM awareness. Lack of a relationship between STEM awareness and gender could be explained with the fact that men and women have similar characteristics. This situation could also be associated with the fact that preservice teachers take education from the same faculty member in the same education faculty and that they have the same learning environments. A related study carried out by Aydın, Saka and Guzey (2017) revealed that secondary school students' levels of attitudes towards STEM did not differ across gender, school type and parents' educational background. Similarly, in another study, Hacıömeroğlu (2017) reported that the elementary school preservice teachers' mean scores regarding the sub-dimensions of the STEM teaching tendency scale (value, attitude, knowledge (and so on) did not differ significantly with respect to the variable of gender. Karakaya and Avgin (2016), in their study, found that parents' educational background did not have much influence on their secondary school children's attitudes towards STEM and that the variables of gender and grade level did not have any influence on the secondary school students' attitudes towards STEM. On the other hand, Simon, Wagner and Killion (2017) examined men and women's ratios of employment and their preferences of STEM career and found no significant difference between the participants' STEM career preferences in terms of gender.

All the findings obtained in the present study as well as in those mentioned above demonstrate that gender is not influential on STEM awareness, STEM attitude and STEM career preference. On the other hand, when the related literature is examined, it is seen that there are several studies reporting that there are considerable differences between men and women in terms of their interest in courses in STEM disciplines and their levels of related knowledge and skills. It is thought that female and male students' attitudes towards science and mathematics differ starting from early 
ages and that this difference continues at older ages and even influences their preferences of profession (Greenfield, 1997). Even though studies carried out in recent years demonstrate that male and female students have similar achievements in science and mathematics, it is seen that there is serious difference between men and women when their career preferences in STEM area are taken into account (Tan, Calabrese-Barton, Kang \& O'Neill, 2013). As for the causes of the difference between men and women in the fields of science and mathematics, it could be stated that teachers do not recognize or encourage female students when these students want to speak in class; that teachers develop teaching strategies for male students; or that they tend to provide more feedback for male students (cited in Greenfield, 1997). Due to various reasons such as cultural pressure on the roles of men and women, influence of the man-dominant culture, lack of the female engineer role model and biological differences between men and women, women are behind men in terms of STEM career areas (Clark-Blickenstaff, 2005). All these reasons are thought to start within the family and to continue at school. It is reported that teachers' direct male students towards STEM careers starting from early ages towards while they take female students away from these areas (Simon et. al., 2017). Both parents and teachers have great responsibilities for solving these problems. Also, the fact that the STEM awareness of the male and female preservice teachers participating in the present study did not differ depending on their gender is thought to be a promising finding.

Lastly, the present study examined whether the preservice teachers' STEM awareness differed with respect to their grade levels. The results revealed that grade level has no significant effect on preservice teachers STEM awareness. However, when we compare the mean scores of each grade, the preservice science and mathematics teachers' STEM awareness's differed depending on their grade levels whereas the preservice primary teachers' scores were similar across all grades. Freshman, sophomore and senior preservice science teachers' STEM awareness's were similar and higher than the junior preservice science teachers. The reason for this result could be the fact that courses of science, mathematics and computer are dominant in the first and second-class levels in the department of Science Teaching. In addition, this result could also be due to the fact that the preservice science teachers are familiar with the engineering process and that these preservice science teachers believe in the need for engineering education for their field (Hacioğlu, Yamak and Kavak, 2016; Marulcu and Sungur, 2012). The fact that junior preservice science teachers had low levels of STEM awareness could be explained with the fact that there are more teaching-based courses in third class. Accordingly, it could be stated that preservice teachers lack the ability to use the Science-Technology-Engineering and Mathematics areas together. When the related literature is examined, it is seen that preservice science teachers do not know much about STEM and that they even need related trainings (Bybee, 2010; Hudson, 2014; Katehi, Pearson and Feder, 2009). In addition, the reason why the science fourth class preservice teachers had high levels of STEM awareness is thought to be the influence of an optional course called "Project Preparation" given in this class level. Also, the fact that within the scope of this course, preservice teachers used their knowledge and skills regarding science-technology-engineering and mathematics in the process of putting forward a concrete product via their project studies might have increased their levels of STEM awareness. This result could also be due to the fact that the preservice teachers were aware of the existence of the science, technology, mathematics and engineering in all areas of daily life (Harkema, Jadrich and Bruxvoort, 2010). Moreover, the result in question could also be associated with the fact that the preservice teachers might have thought STEM education is a beneficial teaching and learning process both for themselves and for their students (Hsu, Purzer and Cardella, 2011; Marulcu and Sungur, 2012).

In addition, it was found that the mathematics first class and fourth class preservice teachers had lower levels of STEM awareness when compared to second class and third class preservice teachers. This result is consistent with the result of another study carried out by Greenfield (1997) to investigate not only the attitudes of male and female students from different grade levels in three different schools towards the courses of science but also their academic achievements in these courses. In the study, Greenfield (1997) found that the attitudes of the participants towards STEM areas were lower at higher grade levels. In the present study, the fact that the secondary school second class and third-class preservice mathematics teachers had high levels of STEM awareness could be due to the fact that especially the third-class level included teaching-related courses and that the preservice teachers did teaching practices using the macro teaching method within the scope of these courses. Preservice teachers take the outcomes in the curriculum into consideration while teaching with the micro teaching technique. The preservice teachers might have had higher levels of STEM awareness as some of the learning outcomes in the mathematics curriculum are related to STEM education. In addition, this result might also be associated with the fact that preservice teachers believe in solving the current problems with the cooperation of a number of disciplines such as science, technology, mathematics and engineering (Moore, Stohlmann, Wang, Tank, Glancy and Roehrig, 2014). The fact that the mathematics first class preservice teachers had low levels of STEM awareness STEM could be explained with the fact that they did not know much about STEM education or about the learning areas in the mathematics curriculum and that they did not take any courses regarding teaching practices or the course of instructional technologies and material design. In addition, the fact that the mathematics fourth class preservice teachers had low levels of STEM awareness might have been attributed to the fact 
that they focused more on the Public Personnel Selection Exam, which they would have to take to get employed after graduation.

In present study, it was found that the primary school preservice teachers' STEM awareness did not differ with respect to their grade levels. Based on this result, it could be stated that the primary school preservice teachers from all the four grade levels had similar STEM awareness. The fact that their STEM awareness did not differ among different grade levels could be associated with the variety of courses they took during their university education. In other words, this result might have been due to the fact that the preservice primary school teachers take numbers of different courses like science, mathematics, Turkish language, social science, history, geography and computer during their undergraduate education. The fact that there such teaching-based courses as science teaching, mathematics teaching and social science teaching especially in third class level allow primary school preservice teachers to be aware of learning areas of different curricula. This fact is thought to create positive influence on their STEM awareness. Therefore, it could be stated that primary school preservice teachers have high levels of STEM awareness regardless of their grade levels.

To conclude, in order to reach 21 st Century goals, governments, educators, and business world should work in harmony. The balanced involvement of each stakeholder is vital. If the governments aim to empower all individuals as life-long learners in today's competitive world, they should start from the beginning. STEM education is thought to be the glorious solution to thrive in a global knowledge driven world. Teachers are key elements for successful STEM education thus we recommend future researchers to explore teachers' STEM teaching integration intentions, skills and attitudes.

\section{References}

Akaygun, S., \& Aslan-Tutak, F. (2016). STEM images revealing stem conceptions of pre-service chemistry and mathematics teachers. International Journal of Education in Mathematics, Science and Technology, 4(1), 56-71. https://doi.org/10.18404/ijemst.44833

Akgündüz, D., Aydeniz, M., Çakmakçı, G., Çavaş, B., Çorlu, M. S., Öner, T., \& Özdemir, S. (2015). A report on STEM Education in Turkey: A provisional agenda or a necessity? İstanbul Turkey: Aydin University.

Apedoe, X. S., Reynolds, B., Ellefson, M. R., \& Schunn, C. D. (2008). Bringing engineering design into high school science classrooms: The heating/cooling unit. Journal of Science Education and Technology, 17(5), 454-465. https://doi.org/10.1007/s10956-008-9114-6

Aydın, G., Saka, M., \& Guzey, S. (2017). Science, technology, engineering, mathematic (STEM) attitude levels in grades $4^{\text {th }}-8^{\text {th }}$. Mersin University Journal of the Faculty of Education, 13(2), 787-802. https://doi.org/10.17860/mersinefd.290319

Baran, E., Cabzoğlu-Bilici, S., \& Mesutoğlu, C. (2015). Science, technology, engineering, and mathematics (STEM) public service announcement development activity. Research Based Activity Journal, 5(2), 60-69.

Bissaker, K. (2014). Transforming STEM education in an innovative Australian school: The role of teachers' and academics' professional partnership. Theory into Practice, 53, 55-63. https://doi.org/10.1080/00405841.2014.862124

Bozkurt-Altan, E., Yamak, H., \& Buluş-Kırıkkaya, E. (2016). A Proposal of the STEM education for teacher training: Design based science education. Trakya University Journal of Education Faculty, 6(2), 212-232.

Bracey, G., \& Brooks, M. (2013). Teachers'training: Building formal STEM teaching efficacy through informal science teaching experience. ASQ Advancing the STEM Agenda Conference, Grand Valley State University, Michigan.

Buyruk, B., \& Korkmaz, Ö. (2016). STEM awareness scale: Validity and reliability study. Journal of Turkish Science Education, 13(2), 61-76.

Bybee, R. W. (2010). Advancing STEM education: A 2020 vision. Technology and Engineering Teacher, 70(1), 30-35.

Capobianco, B. M. (2013). Learning and teaching science through engineering design: insights and implications for professional development. Association for Science Teacher Education, Charleston, SC.

Clark-Blickenstaff, J. (2005). Women and science careers: leaky pipeline or gender filter? Gender and Education, 17(4), 369-386. http://doi.org/10.1080/095402505001450772

Colbeck, C., O’Meara, K., \& Austin, A. (2008). Educating integrated professionals: Theory and practice on preparation for the professoriate. San Francisco: Jossey Bass.

Çorlu, M. S. (2014). Call for manuscripts on STEM Education. Turkish Journal of Education, 3(1), 4-10. https://doi.org/10.19128/turje.181071 
Çorlu, M. S., Capraro, R. M., \& Capraro, M. M. (2014). Introducing STEM education: Implications for educating our teachers in the age of innovation. Education and Science, 39(171), 74-85.

Denson, C. (2011). Building a framework for engineering design experiences in STEM: A synthesis. National Center for Engineering and Technology Education, 169, 1-6.

Ercan, S., \& Bozkurt, E. (2013). Expectations from engineering applications in science education: Decision-making skill. IOSTE Eurasian Regional Symposium \& Brojerage event Horizon 2020, Antalya, Turkey.

Ercan, S., \& Şahin, F. (2015). The usage of engineering practices in science education: Effects of design based science learning on students' academic achievement. Necatibey Faculty of Education Electronic Journal of Science and Mathematics Education, 9(1), 128-164.

Faber, M., Unfried, A., Wiebe, E. N., Corn, J., Townsend, L. W., \& Collins, T. L. (2013). Student attitudes toward STEM: The development of upper elementary school and middle/high school student surveys. $120^{\text {th }}$ ASSE Annual Conference \& Exposition. Atalanta.

Fairweather, J. (2008). Linking evidence and promising practices in science, technology, engineering, and mathematics (STEM) undergraduate education. Board of Science Education, National Research Council, The National Academies, Washington, DC.

Fraenkel, J. R., \& Wallen, N. E. (2003). How to design and evaluate research in education. McGraw-Hill Higher Education.

Gökbayrak, S., \& Karışan D. (2017b). Exploration of sixth grade students' views on STEMM based activities. Journal of Subject Teaching Research, 3(1), 25-40.

Gökbayrak, S., \& Karışan, D. (September, 2017a). Examining the effect of science technology mathematics engineering applications on STEM awareness levels of science teacher candidates. 1. International Educational Research and Conferences on Teacher Education, Uşak, Turkey.

Greenfield, T. A. (1997). Gender - and grade - level differences in science interest and participation. Science Education, 81(3), 259-276. https://doi.org/10.1002/(SICI)1098-237X(199706)81:3<259::AID-SCE1>3.0.CO;2-C

Gülhan, F., \& Şahin, F. (2016). The effects of science-technology-engineering-math (STEM) integration on $5^{\text {th }}$ grade students' perceptions and attitudes towards these areas. Journal of Human Sciences, 13(1), 602-620. https://doi.org/10.14687/ijhs.v13i1.3447

Hacioğlu, Y., Yamak, H., \& Kavak, N. (2016). The effect of engineering design based science education on scientific creativity of science teacher candidates. Educational Researches and Publications Association (ERPA) International Congress on Education, 132-132.

Hacı̈meroğlu, G. (2017). Examining elementary pre-service teachers' science, technology, engineering, and mathematics (STEM) teaching intention. International Online Journal of Educational Sciences, 10(10), 1-11. https://doi.org/10.15345/iojes.2018.01.014

Harkema, J., Jadrich, J., \& Bruxvoort, C. (2010). Science and engineering: Two models of laboratory investigation. The Science Teacher, 76(9), 27-31.

Hsu, M. C., Purzer, S., \& Cardella, M. E. (2011). Elementary teachers' views about teaching design, engineering and technology. Journal of Pre-College Engineering Education Research, 1(2), 31-39. https://doi.org/10.5703/1288284314639

Hudson, P. (2014). Science, Technology, Engineering, and Maths (STEM). R. Gunstone (Ed.), Encylopedia of Science Education (page 1-3), Dordrecht: Springer.

Jonassen, D. H. (2011). Design problems for secondary students. Access date: 09.08.2017, Retrieved from http://ncete.org/flash/pdfs/Design_Problems_Jonassen.pdf, National Center for Engineering and Technology Education.

Karakaya, F., \& Avgin, S. S. (2016). Effect of demographic features to middle school students' attitude towards STEM. Journal of Human Sciences, 13(3), 4188-4198. https://doi.org/10.14687/jhs.v13i3.4104

Karışan, D., \& Yurdakul, Y. (2017). The effects of microprocessors based science technology engineering and mathematics (STEM) investigations on $6^{\text {th }}$ grade students' attitudes towards these subject areas. Adnan Menderes University Education Faculty Journal of Educational Sciences, 8(1), 37-52.

Katehi, L., Pearson, G., \& Feder, M. (2009). National academy of engineering and national research council report: Engineering in K-12 education. Washington D. C.: The National Academies Press. 
Kennedy, T., \& Odell, M. (2014). Engaging students in STEM education. Science Education International, 25(3), 246258.

Kimmel, H., Carpinelli, J., \& Rockland, R. (2007). Bringing engineering into K-12 schools: A problem looking for solutions? International Conference on Engineering Education. Coimbra, Portugal.

Marulcu, İ. (2010). Investigating the impact of a lego-based, engineering-oriented curriculum compared to an inquiry-based curriculum on fifth graders' content learning of simple machines. Doctoral dissertation, Lynch School of Education, Boston College.

Marulcu, İ., \& Sungur, K. (2014). Investigating pre-service science teachers' perspectives on engineers, engineering and engineering design as context. Afyon Kocatepe University Journal of Sciences, 12, 13-23.

Moore, T. J., Stohlmann, M. S., Wang, H. H., Tank, K. M., Glancy, A. W., \& Roehrig, G. H. (2014). Implementation and integration of engineering in K-12 STEM education. In Ş. Purzer, J. Strobel, \& M. Cardella (Eds), Engineering in precollega setting: Research into practice (pp. 35-60). West Lafayette: Purdue Press.

National Research Council (NRC). 2012. A framework for K-12 science education: Practices, crosscutting concepts, and core ideas. Washington, DC: National Academies Press.

Robinson, A., Dailey, D., Hughes, G., \& Cotabish, A. (2014). The effect of a science-focused STEM intervention on gifted elementary student's science knowledge and skills. Journal of Advanced Academics, 25(3), 189-213. https://doi.org/10.1177/1932202X14533799

Şahin, A., Ayar, M. C., \& Adıgüzel, T. (2014). STEM related after-school program activities and associated outcomes on student learning. Educational Sciences: Theory \& Practice, 14(1), 297-322. https://doi.org/10.12738/estp.2014.1.1876

Sanders, M. (2009). STEM, STEM education, STEM mania. The Technology Teacher, 68(4), 20-26.

Schnittka, C., \& Bell, R. (2011). Engineering design and conceptual change in science: addressing thermal energy and heat transfer in eighth grade. International Journal of Science Education, 33(13), 1861-1887. https://doi.org/10.1080/09500693.2010.529177

Seymour, E., \& Hewitt, N. (1997). Talking about leaving: Why under graduates leave the sciences. Boulder, CO: Westview.

Simon, R. M., Wagner, A., \& Killion, B. (2017). Gender and choosing a STEM major in college: Femininity, masculinity, chilly climate, and occupational values. Journal of Research in Science Teaching, 54(3), 299-323. https://doi.org/10.1002/tea.21345

Stinson, K., Harkness, S., Meyer, H., \& Stallworth, J. (2009). Mathematics and science integration: Models and characterizations. School Science and Mathematics, 109(3), 153-161. https://doi.org/10.1111/j.1949-8594.2009. tb17951.x

Stohlmann, M., Moore, T., \& Roehrig, G. H. (2012). Considerations for teaching integrated STEM education. Journal of Pre-college Engineering Education Research, 2(1), 28-34. https://doi.org/10.5703/1288284314653

Sümen, Ö. Ö., \& Çalisici, H. (2016). Pre-service teachers' mind maps and opinions on stem education implemented in an environmental literacy course. Educational Sciences: Theory and Practice, 16(2), 459-476. https://doi.org/10.12738/estp.2016.2.0166

Tan, E., Calabrese-Barton, A., Kang, H., \& O'Neill, T. (2013). Desiring a career in STEM - related fields: How middle school girls articulate and negotiate identities - in - practice in science. Journal of Research in Science Teaching, 50(10), 1143-1179. https://doi.org/10.1002/tea.21123

Tezel, Ö., \& Yaman, H. (2017). A review of studies on stem education in turkey. Journal of Research in Education and Teaching, 6(1), 135-144.

Turkish Association of Industrialists and Businessmen [TÜSİAD]. (2014). A survey of demand and expectations for the workforce trained in STEM Retrieved from http://tusiad.org/tr/component/k2/item/8054 30.03.2017.

Turkish Ministry of Education (2017). Science courses curriculum (3, 4, 5, 6, 7, and $8^{\text {th }}$ grade) presentation. Access date: 05.07.2017, Retrieved from https://tegm.meb.gov.tr/meb_iys_dosyalar.

Turkish Ministry of Education [MoNE]. (2016b). STEM Education Report Ankara: General Directorate of Innovation and Education Technologies.

Wagner, T. (2008). Rigor redefined. Educational Leadership, 66(2), 20-24. 
Yamak, H., Bulut, N., \& Dündar, S. (2014). The impact of activities on $5^{\text {th }}$ grade students' scientific process skills and their attitudes towards. Gazi University Journal of Educational Faculty, 34(2), 249-265.

Yenilmez, K., \& Balbağ, M. Z. (2016). The STEM attitudes of prospective science and middle school mathematics teachers. Journal of Research in Education and Teaching, 5(4), 301-307.

Yıldırım, B., \& Altun, Y. (2015). Investigating the effect of STEM education and engineering applications on science laboratory lectures. El-Cezeri Journal of Science and Engineering, 2(2), 28-40.

\section{Copyrights}

Copyright for this article is retained by the author(s), with first publication rights granted to the journal.

This is an open-access article distributed under the terms and conditions of the Creative Commons Attribution license which permits unrestricted use, distribution, and reproduction in any medium, provided the original work is properly cited. 